\title{
Hjalmar Sundén's Impact on the Study of Religion in the Nordic Countries ${ }^{1}$
}

TOMAS LINDGREN

Umeå University

\begin{abstract}
In this article, I discuss Hjalmar Sundén's theoretical and methodological contributions to the psychological study of religion in the Nordic countries, including a discussion of role theory and Sundén's way of conducting (and presenting) his research. Nordic scholars' use of role theory is analyzed and discussed. My analysis of the state of research reveals that the use of role theory reached its peak during the 1970s. Scholarly interest in the theory declined during the 1980s, and has been virtually abandoned since the mid-1990s. In these earlier studies, the theory was primarily used to elucidate the psychological dynamic of various religious phenomena, rather than to test the theory systematically against data. However, these scholars gave the theory an empirical underpinning, and identified details in the theory that needed to be refined and revised. I propose several possible reasons for the decline in scholarly interest in role theory. Finally, I suggest that Sundén's methodological contributions may have had a bigger impact on the study of religion than his theoretical contributions.
\end{abstract}

Keywords: Hjalmar Sundén, psychology of religion, role theory

Hjalmar Sundén (1908-1993) was awarded a personal professorship in the Psychology of Religion at Uppsala University in 1967. It was the first Nordic chair in the field, and the establishment of the chair meant that the Psychology of Religion became recognized as a separate discipline within Religious Studies. Sundén was a popular professor, who attracted students from all over the Nordic countries, and he played an important role for the Psychology of Religion in Sweden, where the discipline has had greater importance in comparison to other Nordic countries.

Sundén $(1981 a, 22)$ defined the Psychology of Religion as 'the study of religious experiences and behaviors' [all translations from Sundén mine]. He argued, in other words, that it is the specific task of the Psychology of

1 I would like to thank Dr. Nils G. Holm and Dr. Owe Wikström for their comments on an earlier version of this article. The errors that remain are, of course, entirely my responsibility. 
Religion to study the psychological conditions and functions of religious experiences and religious behaviors. Sundén emphasized that the Psychology of Religion is a discipline that must never 'lose contact with the general science of religion, while it must also take into consideration the achievements of general psychology' (1981a, 10). His research and writings testify that he was well acquainted with contemporary research in both of these fields.

\section{Scholar and Author}

Sundén was a prolific scholar and writer. His literary production includes about thirty books and more than 200 articles spanning a wide range of topics. He published a large number of psychological studies of historical individuals, for example St. Augustine $(1959 ; 1987)$, St. Bridget of Sweden (1973; 1981b), St. Teresa of Ávila (1971), Martin Luther (1982), Lars Levi Laestadius (1959, 1969), Dag Hammarskjöld (1966), Nathan Söderblom (1969), Ramakrishna (1959), Selma Lagerlöf, August Strindberg and Albert Camus (1981b, 1983).

With these studies, Sundén laid the foundation for detailed case studies in the psychology of religion, such as Antoon Geels' studies of the mystic Hjalmar Ekström (1980) and the artist Violet Tengberg (1989); Nils G. Holm's (1987) study of the author and artist Joel Pettersson's religious development; Tomas Lindgren's (2004) study of the Swedish ambassador Mohammed Knut Bernström's conversion to Islam; and Lisbeth Rubenson's (1996) study of the author Gunnar Edman's religious experiences.

Sundén (1981b) analyzed poetry and fiction from a psychological perspective: Erik Axel Karlfeldt's poems and Per Lagerkvist's novels, for instance. He introduced an original method in these studies, in which he applied psychological theories to literary figures. The chief aim of these studies was to illustrate the significance of psychological theories and concepts. This methodological approach has subsequently been used by Siv Illman (1992) and Owe Wikström (1982a; 1982b), among others.

Sundén also studied other religious phenomena, such as Zen Buddhism (1970) and the religious development of children (1974). In addition, in the early 1950s he translated Carl Gustaf Jung's Antwort auf Hiob into Swedish (Jung 1954). Through this translation, and by his recurrent use of Jung's theories in the study of religion, he became important for the establishment of analytical psychology in Scandinavia.

Sundén primarily used qualitative methods in his research, making extensive use of personal documents and secondary sources. He also gave 
considerable space to anecdotes, which, rather like William James, he gleaned from sources off the beaten track. Many well-known stories illustrating key components of his thinking were given to him by his students at the Police Academy in Stockholm.

Sundén appears to have been relatively uninterested in methodological issues. In his books and articles, he seldom discusses how he collected, analyzed and interpreted his data. He used theories mainly as hermeneutical tools, with the aim of elucidating the psychological dynamic of religious experiences and religious behaviors. He was eclectic in his use of psychological theories and concepts. Theories from social psychology were combined with cognitive theories, and when the situation called for it, he would deploy concepts from psychoanalytic theory, analytic psychology and biological psychology. An example of this is Sundén's (1969) alternation between Freudian and Jungian concepts in his analysis of Lars Levi Laestadius' religious life.

Sundén rarely problematized his own data. He never discusses, for example, the complex relationship between autobiographical accounts about religious experiences and the experiencing. This is somewhat remarkable, bearing in mind his constructionist way of thinking. It is hard to avoid the conclusion that Sundén - who often criticized naive perceptual realism, i.e., the notion that our perceptions provide accurate descriptions of reality - was himself a naive realist in methodology, in the sense that he assumed that narratives about religious experiences mirror the experiencing.

One problem with Sundén's writings is that he does not separate theory and data in a stringent manner. It is therefore often difficult to determine how well his theoretical discussions are based on empirical evidence. One often gets the impression that psychological theories take precedence over data, that the empirical material was adjusted to the theories, and that the data primarily served as illustrations for his theoretical discussions. When a theory could not explain certain aspects of a religious phenomenon, he usually turned to other theories instead of revising the original theory in light of empirical findings. This eclectic methodological approach had a negative effect on the development of his theories.

Sundén's eclecticism has wielded considerable influence over the psychological study of religion in the Nordic countries. Theories have been combined in a variety of ways; see for example Källstad (1987) and Wiedel (1984). In the most extreme cases, scholars have created networks of theoretical threads which only indirectly refer to empirical data. Instead of testing theories on data, data is used to illustrate the assumed perfection of the theories. 


\section{Role Theory}

Sundén's writings were characterized by an ambition to illuminate the psychological processes involved in religious experiences. His role theory, which aims to answer the question of how religious experiences are psychologically possible, is based on contemporary cognitive and social psychological research. The main concepts of the theory suggest that he was influenced by George Herbert Mead, Theodore Newcomb, Theodore Sarbin and Ralph Linton; but he reinterpreted and reformulated their concepts and included them in a theory of religious experiences.

Sundén (1967) argue that religious experience is a type of perception. Basing his arguments on perceptual psychology, he indulged in polemics with scholars, like Rudolf Otto, who argued that there are religious experiences which are not affected by social and cultural factors. There are, argued Sundén, no raw experiences which reflect reality as it is: in order to perceive something, we must be prepared for it. Perceptions are interpretations affected by the individual's knowledge and prior experiences, i.e. the individual's frame of reference. Frames of references have an impact on what is perceived and how the perceived is understood by the individual. Sundén describes perception as a process in which sensory information input is matched with various frames of references. When the individual identifies a frame of reference that matches the sensory information, the content of the experience can be structured and take on a specific meaning for that person. Religious experiences therefore presuppose, in analogy with other perceptions, access to religious frames of references. Religious experiences thus are 'unthinkable without religious reference systems, without religious tradition, without myth and ritual' $(1959,65)$.

The most central concept of role theory is - unsurprisingly - the concept of role. When Sundén (1981a, 27) defines this concept, he says, with reference to Anne Marie Rochblave-Spenlé, that it is 'a behavioral model that relates to a certain position that an individual occupies in an interactional ensemble (an interactional system)' . Role theory, however, emphasizes that roles can serve as both behavioral and perceptual patterns. Religious roles are important because they function as perceptual patterns for religious experiences.

Role theory has a narrative approach. It is based on the fact that all religious traditions contain a large number of - oral and/or written - stories describing interactions between humans and supernatural beings, such as gods and spirits. Religion, argues Sundén, thus has a dual character. He defines religion as a 'dialogue toward the existence as a totality, but this 
relation is structured through roles and without roles it disappears' (1981a, 34). Sundén argues that access to religious stories facilitates religious experiences, as they give opportunities for role-taking and role-adoption - two central concepts in the theory, which despite their apparent similarity refer to two distinct, but intimately related processes.

Role-taking implies that a person identifies himself or herself with a particular character in a religious story. A problem with the theory is that it does not explain why certain stories are actualized, and why in specific situations specific roles are taken. It seems as if Sundén assumes that roletaking presupposes a thematic similarity between a person's life and the plot of the religious story.

Religions provide human roles 'which fit an interactional system of Godman, gods-man, spirits-man etcetera' (1981a, 35). Role adoption refers to the process whereby the supernatural partner of the taken role (gods, spirits, and so on) is adopted as the believer's frame of reference. This gives rise to an expectation that the supernatural actor will treat the believer in a similar way as he (or she) treated the mythical figure in question. Role-adoption thus makes it possible for the believer to 'anticipate God's actions' (1961, 43). He thinks, in other words, that the believer will have an expectation that 'something will happen, the situation is dual, and it may happen that the experiencing man's whole field of experience is organized as a meeting with a partner' $(1974,95)$.

Sundén suggests that the partnership roles codified in religious stories can provide the basis for the development of a generalized-human role and a corresponding generalized-supernatural role (or generalized-God role); but this requires a deep familiarity with the sacred texts, and regular contact with mythical roles. This role adoption can result in an abstract feeling of a divine presence. However, it may

not allow the same clear structuring as is the case when someone leaves the generalized role by immersion in, for example, a biblical scene, and takes over a specific human role from the myth, when even the role God becomes sharper in contours, the restructuring more concrete, clearer (1981a, 37).

A phase shift occurs when a person alternates between secular and religious interpretations of a particular situation (or vice versa). This is described by Sundén as a shift from a mechanical to an intentional phase, and as a shift from multiplicity to totality: a process is usually described as analogous to the famous perceptual shift in Rubin's vase-face experiment. Religious ex- 
perience is thus, argues Sundén, the result of shifts in the perceptual field brought about by taking on roles learned from sacred texts.

Sundén has been criticized for not having specified the conditions that facilitate a shift from a secular to a religious interpretation (Wikström 1987). This is not an entirely fair criticism, because he has called attention to a number of factors that have a potential impact on an individual's role-taking, such as needs, flexibility and empathy (Sundén 1981a); but the criticism is correct in the sense that he neither examines nor develops the significance of these factors. Some scholars, for example Desmond Ayim-Aboagye (1993), have argued that attribution theory gives a more convincing answer to this question, since it has demonstrated that there are three motivational factors which facilitate religious interpretations: a need/desire to perceive events in the world as meaningful; a need/desire to predict and/or control events and experiences; and a need/desire to protect, maintain and enhance one's self-concept and self-esteem.

Sundén thus regards religious experiences mainly as a consequence of social learning. It is therefore hardly surprising that he emphasizes the importance of analyzing religious socialization. Sundén makes a distinction between three types of agents of socialization (in Sundén's own discussion, he usually focuses on the parents), and two types of socialization processes.

Sundén distinguishes between secure, insecure and over-secure agents of religious socialization. Insecure agents have an ambivalent and often an anxiety-ridden relation to religion, and they tend to convey an ambivalent or negative attitude to religious beliefs, values and practices.

Secure agents typically have positive experiences of religion and they usually convey a positive attitude to religious beliefs, values and practices. This attitude is due to the fact that religion is associated for them with positive emotional experiences. Sundén calls these agents secure because 'they, according to their own conviction, shall be mere mediators of the tradition by which God speaks to man, and man speaks to his God' $(1974,111)$.

Over-secure agents convey religious beliefs, values and practises in an authoritarian way. These persons are usually 'fully convinced of having God on their side against their children' $(1974,113)$. Sundén thinks that these people try to convince others about the truth of their own faith, but that

it is themselves that they want to convince, because deep down they are doubtful. They are very scrupulous regarding doctrines, but completely unscrupulous regarding fellow human beings, and not least children $(1974,18)$. 
Their ambition to control others' thoughts and behaviors are liable to have a negative effect on their children's religious development.

Sundén distinguishes moreover between two different ways to convey religion: mere verbal and total religious socialization.

'Mere verbal socialization' implies that the agents talk about religion, but rarely, if ever, practice religion together with their children. Religious socialization is thus more a question of theoretical instructions than of the experience of religious practises. Such an approach, argues Sundén, will impede the child's capability for role-taking. It is mainly insecure and oversecure individuals who convey religion in this way.

'Total socialization' implies that the agents convey the cognitive, emotional and behavioral aspects of a religion in an experience-based way. Those who follow this approach are usually themselves secure individuals, and they will include their children in their own religious life. Religious socialization is in this case more a question about the experience of religious life and the imitation of role-models than of theoretical instructions. Such an approach will enhance the child's capacity for role-taking.

The uniqueness of role theory is thus its focus on how sacred stories enable role-taking, role-adoption and experiences of interaction between humans and supernatural beings. In subsequent research, scholars have confirmed that religious frames of references have a strong impact on people's religious experiences. They have also shown that other types of roles associated with supernatural beings can have similar functions as mythical roles. Scholars have moreover demonstrated that the generalized-God role may be much more important for peoples' religiosity than Sundén claimed.

\section{The Theory in Practice}

Sundén's theory has generated empirical research, especially in the Nordic countries, but also elsewhere (see for example Capps 1982; Hijweegwe 2004; Lans 1978). In this section, I will discuss several Nordic studies that refer explicitly to Sundén's role theory. I do not include scholars whose argumentation is similar to Sundén's reasoning, but who do not refer to him explicitly, such as Lauri Honko (1961; 1971).

Gunnar Hillerdal and Berndt Gustafsson (1973) found, in an empirical study on visions of Jesus, that their data 'proves long passages of Sundén's theories'. The authors argue, however, that they have documents which indicate that religious visions can occur without a deep knowledge of religious texts - 'without a long period of role play', but that this requires that 
the experience has been preceded by 'an exceptionally intense psychological engagement' $(1973,133)$. What they mean by this statement is, however, somewhat unclear.

Hillerdal and Gustafsson argue that these experiences indicate that Sundén's theory needs to be revised. There is however a problem with this objection. It is true that Sundén argued that religious frames of references are necessary conditions for religious experiences, and that he thought that they are facilitated by a long period of role-taking. Role theory in general, however, does not postulate that prolonged role playing is a necessary condition, merely a favorable one. Hillerdal and Gustafsson do not report one single case that actually contradicts Sundén's claims.

Moreover, even necessary conditions are not sufficient conditions. It is not enough to have a religious frame of reference for the appearance of a religious experience. It takes something more, such as 'an exceptionally intense psychological engagement' - if that means a motivation to interpret life in a religious manner; but even if a person has internalized a religious frame of reference and is motivated to interpret life in a religious way, it does not necessarily imply - as Sundén seems to think - that the individual's religious experience merely reproduces the content of his or her frame of reference. The creative components of religious experiences are difficult to explain from a role theory perspective. Moreover, the theory fails to explain the finding that LSD experiences are occasionally interpreted with a different religious language than the experient's own (Grof 1980). However, these critical issues are not discussed by Hillerdal and Gustafsson.

Thorvald Källstad (1974) used role theory in a hermeneutical study on John Wesley's religious development. He demonstrated, among other things, how Wesley's familiarity with Biblical texts, such as 2 Pet. 1:4, Mk. 12:34 and Ps. 130, promoted a role-taking and role-adoption process which eventually resulted in a conversion. Källstad summarizes his role theory interpretation in this way:

Using Sundén's theory of role psychology we can formulate this in the following way: Wesley is conversant with the biblical tradition and is able to identify himself with one of its figures. As a result of this identification he adopts the role 'God'. Consequently, it is possible for him to anticipate God's action in his position. When events take place correspond to these anticipations, Wesley is certain that he is acting together with a real 'living other' as his partner. Expectation turns into interaction. (Källstad 1974, 237.) 
Källstad's interpretation of Wesley's religious development is - as the quotation above illustrates - strictly 'orthodox', in the sense that he simply applies Sundén's concepts to the empirical material. To a large extent, he actually uses data to illustrate the theory. When role theory is unable to explain certain aspects of Wesley's religiosity, he turns to Leon Festinger's theory of cognitive dissonance, and a number of other theories. This eclectic methodological approach, however, means that his study does not contribute much to the development of role theory.

In a subsequent study, Källstad (1987) used the same theory in order to elucidate the psychological processes that structured the religious experiences of the Swedish mystic Ruth Dahlén. This is also a hermeneutical study, based on personal documents. His role theory interpretations are surprisingly incomplete, expressed as summarized comments. This can be illustrated with his interpretation of Dahlén's religious vision in Uppsala Cathedral, 1953:

Ruth Dahlén's early role play, her ability for dramatic empathy, and her acquired belief in angels is a psychological condition for the initial process of the temple vision with its angelic image activation $(1987,97)$.

Källstad combines role theory with several other theories in this study, for example attribution theory. His research thus illustrates the Sundén-inspired eclecticism that characterizes many of the studies based on role theory.

Thorleif Pettersson (1975) refers to role theory in an experimental study on the retention of religious experiences. Pettersson initially tested how the subjects (all of them were students) imagined certain specified religious symbols. Thereafter, they were shown pictures of religious symbols of unusual design. Finally, a couple of weeks later, he studied the participants' memories of the symbols they were exposed to during the experiment.

Pettersson found that their memories were more similar to their imaginary symbols than to those they had actually been shown. This finding supports Sundén's argument that a person's frame of reference influences the structure and content of his or her religious experiences. (This conclusion is also supported by an experiment conducted by Jan van der Lans [1978], a Dutch psychologist of religion, on religious experiences during Zen meditation.) Pettersson also observed that memories tend to be generalized across time. He wondered if this might indicate that specific roles are transformed into generalized roles during the cognitive processing of religious experiences. 
Pettersson's experimental and quantitative approach differs from most studies based on role theory, in that he sets out to examine Sundén's concepts empirically. Both Pettersson's and Lans' studies constitute in this respect important contributions to the research field. A critical objection, however, concerns the question whether experiences of religious symbols are comparable to religious experiences, which I seriously doubt.

Sundén (1961) showed an early interest in the religious life of older individuals, and claimed, among other things, that in their religiosity experiences of God's guidance are prominent. Owe Wikström (1975) conducted an empirical study of elderly people's experiences of God's guidance in northern Sweden. He found that among the 27 informants he interviewed such experiences were common. These individuals had been familiar with religious literature during their upbringing, which made it possible for them to identify, in various situations, with a range of different human roles in religious stories.

Wikström also observed the importance for the experience of God's guidance of social roles, i.e. people in the subject's social milieu who are associated with supernatural beings. Familiarity with these roles laid the foundation for the development of a generalized-God partner role, which they perceived as loving and caring. This role provided a perceptual pattern that facilitated experiences of God's guidance. He concluded that this role can function as 'an integrating and stabilizing factor in the personality' (1975, 176). Wikström thus found that the generalized-God partner role is more important than Sundén had suggested in his writings.

Hans Åkerberg (1975) used role theory, and a number of other theories, in a study attempting to elucidate the psychological dynamic of critical moments in the life of Nathan Söderblom, Archbishop of Uppsala. He showed, among other things, how Söderblom's identification as a young man with the Israelites bitten by snakes in the desert (John 3: 14 [cf. Numbers 21: 4-9]) had structured his transformative conversion (or religious awakening). The religious crisis that preceded this conversion/awakening was caused by a conflict between the evangelical piety of his upbringing and a historicalcritical view of the Bible. By taking on a role from the Bible, he was able to experience the merciful God, which eventually resulted in a strong belief in God's grace. Åkerberg $(1975,175 f)$ summarizes his interpretation as follows:

The human role that has been taken over from the Biblical material has the described characteristics of 'the snake-bitten Israelites' situation, and the adopted role 'God' is characterized by the merciful, forgiving God, or transferred to the text from the New Testament, of the Crucified Christ. 
At one point Åkerberg actually contradicts Sundén's role theory, when he incidentally comments, with reference to his own interpretations, that religious experiences 'usually [emphasis added] presuppose some theoretical knowledge' $(1975,177)$. He thus suggests that access to a religious frame of reference is not a necessary condition for religious experiences. This is a remarkable statement, that ought to have been problematized and discussed extensively; but instead of discussing the implications of this statement, he discusses the importance of motivation and the possibility that some religious experiences might be rooted in religious texts - 'in the word of the Bible'. What is meant by this remains shrouded in mystery.

In his analysis of William James' description of the conversion process, however, Åkerberg made an important observation that has significant implications for role theory, namely the importance for the occurrence of role-taking of a conscious act of self-surrender.

Johan Unger (1976) conducted a qualitative study that aimed to clarify the structure and content of experiences of God. The material consisted of 57 essays written by theology students at Uppsala University. Unger identified seven categories of experiences in his data: perceptions of God's presence, perceptions of God's action, perceptions of God's call, perceptions of God's features, perceptions of God as totality, subliminal perceptions of God and other perceptions of God. Although the author stated that he did not intend to analyze the psychological dynamic of the experiences $(1976,117)$, he interpreted some parts of the material from a role theory perspective. However, these interpretations are so fragmented that they do not provide any significant contributions to the development of the theory; but his critical discussion highlights some weaknesses in role theory, such as the lack of precision and systematization of the main concepts, and the theory's weak empirical underpinning $(1976,132)$.

Nils G. Holm (1997a, 28) argues that role theory has its strongest explanatory power in studies of intense religious experiences that are based on sacred texts, and this is supported by evidence cited in his doctoral dissertation (Holm 1976), where he used role theory (and some other theories) in a psychological study on glossolalia and baptism in the Holy Spirit. The primary material consisted of 69 in-depth interviews with 65 Swedishspeaking Pentecostals in Finland. He concluded that glossolalia and baptism in the Holy Spirit are related to each other, and that they are part of a process that includes 'a conflict between fears that the glossolalia is self-produced and a desire to be able to indulge in it' $(1976,192)$.

Holm identifies three stages in this process, which he calls the preparatory stage, the breakthrough and the persistency. During the preparatory stage, the 
interviewees acquired knowledge about glossolalia and spiritual baptism through instruction and imitation of role models up from the Bible (mostly from the Acts of the Apostles) and the social environment (1976, 107-30). This process results in an expectation that the informants should also speak in tongues and experience a spiritual baptism; Holm describes this expectation as taking on the role of one who awaits the Spirit. At the same time, the supernatural role is adopted, resulting in an expectation that God would act. Glossolalia - which Holm describes as a nonsense language that is perceived as an unknown language by the believers - was the incitement which led to the taking on of the role of one who is baptized in the Spirit. The interviewees interpreted glossolalia as a divine act and perceived themselves consequently as baptized in the Spirit: the breakthrough (1976, 131-64). The last stage concerns the factors which influences the perpetuation of the informants' glossolalia $(1976,165-88)$.

Jan Hjärpe $(1995,193)$ argues that the attraction of religion is rooted in religious experiences and 'the fact that [religion] works in the individual's life'. Religions convey patterns of interpretations for the individual's experiences. These frames of references can lead to the experience of confirmation of a religion's beliefs and practises, which in turn entails that this religion entails that this religion is perceived as relevant by the individual. Hjärpe thinks that a religion's chance of survival is dependent on its ability to 'give expression and form to the individual's religiosity'. His understanding of the interaction between a religious tradition and the individual is mainly based on Sundén's theories.

Hjärpe (1977) used role theory in a study of the religious vision that came to be the foundation for the Prophet Mohammad's vocational certainty. He believes that religious texts, beliefs and ideals of piety in the social environment were important for the Prophet's religious experiences. He argues that Muhammad took over the role of the Christian desert hermits, a conclusion supported by the Prophet's habit of regularly retreating to Hira, a mountain outside of Mecca, in order to practice spiritual exercises. This role-taking (and role-adoption) resulted in an expectation that he too would achieve the same kind of extraordinary experiences as the desert hermits did, and that he would acquire a book similar to the one used by the desert hermits as devotional literature, i.e. a lectionarium (or in Arabic, al-Quran).

Shamanism is a cross-cultural phenomenon that has captured the attention of many scholars over the past century. The phenomenon has been studied from various psychological perspectives. Anna-Leena Siikala (1978) analyzed the Siberian shamans' ritual techniques from a role theory 
perspective. Based on a large number of ethnographical accounts, she describes shamanic ecstasy rituals as communicative acts where shamans convey information between this world and supernatural worlds. The trance rituals are social activities in which shamans act on behalf of local communities. There is an interaction in every ritual between the shamans, the spirits, and the groups who witness the events. Siikala understands this interaction as 'fundamentally an ecstatic role-taking technique' (1978, 28). The shaman's role-taking takes place in relation to both the spiritual world and the audience.

A person must master the techniques of ecstasy in order to act as a shaman and be recognized as such by the local community. This requires a process of initiation where the adepts increase their knowledge about the supernatural worlds and improve their ecstatic abilities, suggests Siikala $(1978,311)$. The ritual trance technique becomes in this way rooted in the religious tradition and the social context in which the ritual is performed.

Siikala argues that the induction of trance is a process which is characterized by an actualization of spirit-helpers and an intensified identification with these roles. This coincides with an intensification of sensory stimuli, usually in the form of a rhythmic drumming. The processional shift into an altered state of consciousness is also affected by the shaman's motivation, knowledge, and the audience's attention and expectations. The shaman's altered state of consciousness, argues Siikala, cannot be attributed solely to his role-taking. She observed that the depth of the trance varies during the ritual, a fact that can be explained by the multitude of factors which affect altered states of consciousness. Even during deep states of ecstasy, the shamans tend to retain contact with the audience. This indicates that shamans still maintain some kind of reality orientation in states of deep trance. (Note that Antoon Geels [1990, 115] made a similar observation in a study of a Tibetan shaman in Nepal.)

The trance ritual reaches its climax when the shaman meets the spirithelpers. These encounters are manifested in different ways in different rituals. In some rituals, the shaman is transformed into the spirit role, i.e. role identification. In other rituals, the shamans create an illusion that there is an interaction between them and spirits outside their bodies, i.e. a dual role situation. In a third type of rituals, the shamans describe verbally their encounters with the spirits based on what they see and hear $(1978,333-7)$.

Siikala refers to Sundén, but she mainly uses Theodore Sarbin's version of role theory. There is no doubt that her interpretations of the rituals deepen our knowledge about the psychology of shamanism. Her analysis confirms 
Sundén's thesis that internalized religious narratives influence peoples' experiences and behaviors; but her analysis also demonstrates that role-taking and role-adoption can be reversed, in the sense that the shamans take over supernatural roles and adopt human roles. They alternate, within relatively short time intervals, between taking supernatural roles and adopting human roles, and taking human roles and adopting supernatural roles. The shamans' behavior during trance rituals thus indicate that role-taking and role-adoption are more complex processes in role theory than Sundén suggests.

During the 1980s, three Swedish scholars used role theory in studies of prayer: Björn Wiedel (1984), Thorvald Källstad (1984) and Gunnar Hillerdal (1985). Since their interpretations are quite similar, I will only discuss the first of these.

Wiedel (1984) studied the form and function of prayer in the Swedish Alliance Mission Church. His data consisted of questionnaires and interviews with active members of the congregation. He describes prayer as a dual role situation where the person praying takes the role of interceder and adopts the role of God. His analysis of the data revealed, among other things, that the God role was perceived as 'more real' if the interceder role was important for the individual.

The informants acquired several roles during their religious socialization, which they could take over in various situations, from which a generalizedhuman role could be developed. Wiedel identified a role system within the Swedish Alliance Mission Church which includes two dual role structures: child-father and servant-master. When the prayer act is structured by the child-father system, it often results in experiences of security, joy and peace. The taking on of the servant role tends to coincide with a specific type of self-awareness that includes the notion that man and God are dependent on each other.

Furthermore, Wiedel argues that prayer typically undergoes two distinct phases which he calls functional prayer and expressive prayer. The term functional prayer refers to the kind of prayer that is rooted in the religious tradition. This type of prayer actualizes the individuals' religious belief and helps to maintain his or her religious system of meaning. The term expressive prayer refers to the kind of prayer which occurs when God is perceived as a real partner. The individual therefore experiences these prayer acts as intimate interactions with a living person (1984, 240-59).

Karl Geyer (1989) refers to role theory in a discussion of the theoretical problems that arise when one asks how to improve the quality of the Swedish Church's confirmation classes. Geyer argues that there are several reasons 
to modify Sundén's 'mechanical' description of the perceptual process. He agrees with Sundén that perception is selective and constructive in nature, but he thinks that the perceptual process is more explorative and inventive than Sundén suggests. Geyer relativizes the significance of frames of references for our perceptions by referring to pragmatic action theory. It is true that knowledge and experiences creates expectations, Geyer says, but they instigate actions as well. Humans are future-oriented beings and we create a multitude of hypotheses concerning how we might be able to realize our goals. Our aims in life have an impact on what is perceived as relevant information.

The first step in the perceptual process, suggests Geyer, is that the individual determines the meaning, and then impressions are registered on the basis of this meaning. The meaning can, of course, be a selection criterion for what is observed; but the meaning also includes assumptions about which objects we can interact with and which objects we can anchor a specific meaning in. The selection criterion can allow observations of all objects that are not excluded by the meaning. This means that the meaning only weeds out what is not perceived as relevant. There is hence a potential for innovation in all perceptions. In other words, there are good reasons to be skeptical about the conclusion that religious experiences merely reproduce the content of our frames of references.

Pertti Järvinen (1991) used role theory in a study of six schizophrenic patients' religious experiences. He found that all of the participants interacted with insecure or over-secure parents during their upbringing. Their religious socialization was in all cases entirely verbal, which impeded their ability to go into interactive (dual) role situations. Their role behavior deviated from the pattern that Sundén described as typical for other people.

The excessive motivation in the patients' lives forces them into powerful defensive positions, and in this state there is often a reversal of role-taking and role-adoption. The psychotic takes on the role of God in order to find a defense against overpowering anxiety attacks, or in order to cope with his or her incomplete socialization into socially meaningful roles. (Järvinen 1991, 233.)

Thus, there seem to be some similarities between the role behavior of psychotics and shamans, a conclusion that does not necessarily imply that shamans are psychotics (or vice versa). We do not in fact know how common it is for other categories of people to identify with supernatural roles. Järvinen's study is original and it reveals a lacuna in role theory research that needs to be addressed with more extensive studies based on a large empirical material. 
Role theory has been used only once in the study of African religion. Desmond Ayim-Aboagye (1993) used role theory and attribution theory in a study of the impact of myths on the experience of healing in Ghana. The study was based on participant observation and qualitative interviews with 6 healers and 22 'patients'. The analysis of the material revealed, among other things, that the patients took roles from the myths and the social group. At the same time, they adopted the supernatural roles (gods or spirits) associated with these human roles. This interaction restructured their field of experience, which evoked a healing experience. Healing was interpreted as acts of gods or spirits. In this study, the prevalence of role-taking and role-adoption is also worth noting in dreams which resulted in healing experiences $(1993,175)$.

The most ambitious attempt to develop Sundén's role theory has been presented by Nils G. Holm (1997a), who developed a holistic approach that integrates theories from social psychology and depth-psychology (primarily, role theory and object relations theory) into a comprehensive theory known as integrated role theory.

In this theory, Holm makes a distinction between two different domains of existence known as the outer existence space and the inner existence space. The inner existence space refers to the intrapsychic sphere where various mental mechanisms register, process and store information about everything that happens to us. He emphasizes that we are not only equipped with mental mechanisms that store and categorize our experiences; there are also functions that magnify, reduce, combine, condense and symbolize memories. Thanks to our capacity for fantasy and day dreaming, imagined material can be added to our memories. This means, argues Holm, that we have an innate tendency to create symbols that summarize our positive and negative experiences. It is due to our ability to create symbols that we are capable of expressing complex experiences that may be difficult to formulate in words. 'The inner existence space is', in other words,

the scene of all mental functions of which the individual is capable. Here we may encounter cognitive structures, emotional charges, volitional actions, relational patterns, and so forth. At a very early stage, we acquire a function that is central to all human life: the symbolic function (Holm 1997b, 80).

The outer existence space consists of condensed human experiences that are externalized as symbols in the culture. These symbols consist of condensed images, language and behavioral structures. There are different kinds of ob- 
jectified symbolic structures in culture, such as private, social and religious symbolic structures $(1997 b, 81)$. Religious symbols have been formalized into myths and rituals in the outer existence space. Myths are thus 'a collective processing on a symbolic level of central motifs in the inner existence space', and rituals are 'culturally shaped patterns of behavior with a symbolic function for individuals' and groups' interaction and survival' (1997a, 38).

There is a continuous interaction between what happens in these two domains of existence. It can be described as an ongoing dialectical process characterized by externalization and internalization. When a person discovers a correspondence between internal experience structures and cultural symbols, an inner role-taking occurs 'that is not merely a given quantity at the cognitive level but also something that seizes one's deepest and perhaps earliest individual memories' $(1997 b, 83)$. Inner role-taking can have either positive or negative consequences for the individual. This is due to the fact that the internal symbols are based on our positive and negative experiences. Holm believes that difficulties with taking on internal roles are related to complications during the conveying of culturally sanctioned symbols (1997a, 134).

Tomas Axelsson $(2008 ; 2011)$ thinks that Holm's integrated role theory can increase our understanding of the psychological processes that are involved in the attractiveness of fiction. He argues that the increased consumption of film might be due to the fact that recurrent motifs in films have a resonance in our inner existence space.

\section{Discussion}

When evaluating a scholar's impact, it seems natural to focus on his or her theoretical and methodological contributions. Sundén is unquestionably best known as the creator of role theory. However, this does not mean that he merely - or even primarily - used role theory in his own research. The question is whether Sundén even claimed to have created a theory. Karl Geyer $(1989,33)$ writes: 'What [Sundén] does is, in a role theory perspective, to describe how the religious experience is psychologically possible. From the role theorists he borrows a conceptual apparatus.' This can hardly be defined as a scientific theory - at least if by theory we mean a system of statements which describe and explain a phenomenon in a consistent and coherent manner (cf. Molander 1993, 37).

Sundén presented his ideas and observations in an exceptionally unstructured, almost impressionistic manner. The basic concepts in the theory are 
vaguely defined. This vagueness, in turn, lays the foundation for exegetical disputes about what Sundén really meant. Geyer $(1989,33)$ is certainly right when he says that other scholars were responsible for summarizing and systematizing Sundén's scattered thoughts, which they generously presented as 'Sundén's role theory'. This occurred at a time when Sundén was more often using other theories to shed light on the psychological dynamic of religious experiences.

There is no doubt that role theory had its greatest influence on the study of religion during the 1970s. During this decade, several studies were published (mainly by Sundén's doctoral students) that systematized, applied and refined (and occasionally tested) Sundén's theory. The aim of their research was primarily to increase our understanding of various religious phenomena, such as conversion, religious development, glossolalia and experiences of God's guidance. Role theory was used to illustrate the psychological processes involved in the religious phenomena under study. In these studies, scholars discovered that there were details in the theory that needed to be refined and revised. These scholars gave role theory a much needed empirical base; but it should be noted that the main purpose was rarely, if ever, to examine the theory critically. The theory was never tested systematically against data. It was used instead as a hermeneutical tool in order to make sense of various religious phenomena. This implied sometimes quite speculative 'translations' of empirical data into a theoretical language, as is the case in some sections of Källstad's (1974) and Åkerberg's (1975) studies. This approach to theory and empirical data persisted during the following decade; see for example Wiedel (1984).

Scholarly interest in role theory declined during the 1980s, as is reflected by a steady decline in the number of studies based on the theory. Those studies that were published did not give any significant contributions to the development of the theory. This coincides with the paradoxical fact that the scientific community outside of Europe was now becoming more aware of Sundén's theory, and the prestigious Journal for the Scientific Study of Religion dedicated an entire volume to the theory in 1987.

Scholarly interest in role theory has been virtually non-existent since the mid-1990s. This is somewhat surprising when one takes into consideration that social constructionism, which is consistent with Sundén's thinking (Belzen 1995), was established as a dominant perspective in Religious Studies during these years.

There are several factors that might explain the failing interest in role theory. One possible reason is the obscure and unsystematic presentation of 
the main concepts of the theory. This inevitably leads to a host of problems when one wants to operationalize and test the theory. It may also be due to the fact that the theory is designed in such a way that it is extremely difficult to falsify. A theory that is always - or almost always - correct quickly becomes uninteresting. The fact the theory was tied to a particular person, and on many occasions was even presented as that person's property, has probably also had an inhibiting effect on some scholars, particularly those who admired or feared him, who otherwise might have considered subjecting the theory to scientific scrutiny.

Nils G. Holm $(1997 a, 28)$ has correctly pointed out that the importance role theory ascribes to religious texts implies that it loses its relevance as peoples' familiarity with religious narratives declines. This may be one reason why Nordic scholars have showed little interest in the theory during recent decades; but the main reason for the declining interest in role theory is probably more prosaic. Interest in various theories tends to fluctuate over time, and this is not only due to the fact that some theories appear to be more coherent or have a better empirical underpinning than other theories. Some theories are preferred simply because they are more popular than others. In recent years, scholars of religion have been attracted by other approaches: object relations theory, coping theory, attachment theory and cognitive theories, for instance. The irony in this context is that this eclecticism is reflected in Sundén's own scholarly work; he too tended to shift between various theories that were popular at the moment.

What I have said above does not necessarily entail that the time for role theory has passed and that it should be shipped to the cemetery for dead scientific theories; but the key concepts must be specified and tested systematically on empirical data, with both qualitative and quantitative methods, if the theory is to successfully compete on the market of scientific theories. This presupposes that the theory needs to be decoupled from Sundén as a person and to be reformulated on the basis of contemporary psychological research. Some parts of the theory, such as the description of our cognitive processes, are obviously outdated according to contemporary psychological research. Jacob van Belzen (1995; 1996), for example, has convincingly argued that role theory needs to be developed in relation to recent theoretical developments in narrative psychology.

Although Sundén is best known as the creator of role theory, there are good reasons to argue that his most enduring contribution is methodological. Sundén was sympathetic to qualitative methods and primarily used this type of method in his own research. His methodological preferences gave 
legitimacy to the use of qualitative methods in the psychological study of religion. He has been - for better or worse - a role model for many scholars. Various types of qualitative methods have consequently been used in most psychological studies on religion in the Nordic countries. There has been an impressive development within the qualitative study of religion during recent decades: see for example Ståhle (2004), Liljas Stålhandske (2005) and Lindgren (2005). Much of the criticism that can be leveled against Sundén's use of qualitative methods cannot be directed at most psychological studies on religion after Sundén.

Bibliography

\section{Axelson, Tomas}

2008 Film och mening. En receptionsstudie om spelfilm, filmpublik och existentiella frågor. Uppsala: Uppsala universitet. (Acta Universitatis Upsaliensis, Psychologia et Sociologia Religionum 21.)

2011 Människans behov av fiktion: den rörliga bildens förmåga att beröra människan på djupet. - Kulturella perspektiv 2, 33-42.

Belzen, Jacob A. van

1995 On Religious Experience: Role Theory and Contemporary Narrative Psychology. - Nils G. Holm \& Jacob A. van Belzen (eds), Sundén's Role Theory: an Impetus to Contemporary Psychology of Religion, 47-76. Åbo: Åbo Akademi. (Religionsvetenskapliga skrifter nr 27.)

1996 Beyond a Classic? Hjalmar Sundén's Role Theory and Contemporary Narrative Psychology. - The International Journal for the Psychology of Religion 6, 181-99.

\section{Capps, Donald}

1982 The Psychology of Petitionary Prayer. - Theology Today 39, 130-41.

\section{Geels, Antoon}

1980 Mystikern Hjalmar Ekström. En religionspsykologisk studie av hans religiösa utveckling. Lund: Doxa.

1989 Skapande Mystik. En psykologisk undersökning av Violet Tengbergs religiösa visioner och konstnärliga skapande. Löberöd: Plus Ultra.

1990 Extatisk religion: Ett bidrag till mystikens psykologi. Lund: Lunds universitet. (Religio 33.) 


\section{Grof, Stanislav}

1980 LSD Psychotherapy. Pomona: Hunter House.

\section{Hijweegwe, Nicolette}

2004 Bekering in Bevindelijk Gereformeerde Kring: Een Psychologische Studie. Kampen: Uitgeverij Kok.

\section{Hillerdal, Gunnar}

1985 Bönhörelse: Utsagor i vår tid. Stockholm: Proprius förlag.

\section{Hillerdal, Gunnar \& Berndt Gustafsson}

1973 De såg och hörde Jesus. Om kristusuppenbarelser $i$ vår tid. Stockholm: Verbum.

\section{Hjärpe, Jan}

1977 Rollernas Muhammed. - Religion och Bibel 36, 63-72.

1995 Legitimering av krig och fred i muslimsk tankevärld. - Svensk Teologisk Kvartalskrift 3 103-10.

\section{Holm, Nils G.}

1976 Tungotal och andedop. En religionspsykologisk undersökning av glossolali hos finlandsvenska pingstvänner. Uppsala: Uppsala universitet. (Acta Universitatis Upsaliensis, Psychologia Religionum 5.)

1987 Joels Gud: En religionspsykologisk studie av Joel Pettersson. Mariehamn: Ålands Tidnings-Tryckeri AB.

1997a Människans symboliska verklighetsbygge: En psykofenomenologisk studie. Åbo: Åbo akademi. (Religionsvetenskapliga skrifter nr 40.)

1997b An Integrated Role Theory for the Psychology of Religion: Concepts and Perspectives. - Bernhard Spilka, \& Daniel M. McIntosh (eds), The Psychology of Religion: Theoretical Approaches, 73-85. Boulder: Westview Press.

\section{Honko, Lauri}

1969 Role-taking of the Shaman. - Temenos 4, 26-55.

1971 Memorat och folktroforskning. - Anna Birgitta Rooth (ed), Folkdikt och folktro, 93-105. Lund: Gleerup.

\section{Illman, Siv}

1992 Vere adest: Religionspsykologisk tolkning av närvarotemat i Olov Hartmans romaner. Åbo: Ảbo Akademi.

\section{Jung, Carl Gustav}

1954 Svar på Job. Stockholm: Natur och Kultur.

\section{Källstad, Thorvald}

1974 John Wesley and the Bible: A Psychological Study. Stockholm: Nya bokförings AB. (Acta Universitatis Upsaliensis, Psychologia Religionum 1.)

1984 Bönens Psykologi. - Svensk Teologisk Kvartalstidskrift 3, 107-13. 
1987 Levande Mystik. En psykologisk undersökning av Ruth Dahléns religiösa upplevelser. Delsbo: Åsak.

\section{Lans, Jan M. van der}

1978 Religieuze Ervaring en Meditatie: Een Godsdienstpsychologische Studie. Deventar: Van Loghum Slaterus.

\section{Liljas Stålhandske, Maria}

2005 Ritual Invention: A Play perspective on Existential Ritual and Mental Health in Late Modern Sweden. Uppsala: Uppsala Universitet.

\section{Lindgren, Tomas}

2004 The Narrative Construction of Muslim Identity: A Single Case Study. - Archiv für Religionspsychologie/Archive for the Psychology of Religion 26, 51-73.

2005 The Narrative Construction of Muslim Prayer Experiences. - International Journal for the Psychology of Religion 2, 159-74.

\section{Molander, Bengt}

1993 Vetenskapsfilosofi: En bok om vetenskapen och den vetenskapande människan. Stockholm: Bokförlaget Thales.

\section{Petterson, Thorleif}

1975 The Retention of Religious Experience. Stockhom: Almquist \& Wiksell. (Acta Universitatis Upsaliensis Psychologia Religionum 3.)

\section{Rubenson, Lisbeth}

1996 Ögonblicket - det förvandlade: En religionspsykologisk studie av en livsavgörande gudsupplevelse i Gunnar Edmans liv. Uppsala: Uppsala universitet. (Acta Universitatis Upsaliensis Psychologia et Sociologia Religionum 11.)

\section{Siikala, Anna-Leena}

1978 The Rite Technique of the Siberian Shaman. Helsinki: Suomalainen Tiedeakatemia. (FF Communications.)

\section{Ståhle, Göran Viktor}

2004 Det religiösa självet i praktik vid ett hinduiskt gudinnetempel: ett kulturpsykologiskt angreppssätt för religionspsykologi. Uppsala: Uppsala Universitet.

\section{Sundén, Hjalmar}

1959 Religionen och rollerna. Stockholm: Svenska kyrkans diakonistyrelses förlag.

1961 Människan och religionen. Stockholm: Diakonistyrelsens bokförlag.

1964 Om ålderdomen: en orientering. Stockholm: Diakonistyrelsens bokförlag.

1966 Kristusmeditationer i Dag Hammarskjölds vägmärken. Stockholm: Diakonistyrelsens bokförlag. 
1969 Älgskyttar, helgon och exegeter: några religionspsykologiska essäer. Stockholm: Wahlström \& Widstrand.

1970 Zen: historisk, analys och betydelse (andra upplagan). Stockholm: Wahlström \& Widstrand.

1971 Teresa av Avila och religionspsykologin. Uppsala: Uppsala universitet. (Acta Universitatis Upsaliensis, Studia Historico-Ecclesiastica Upsaliensia 20.)

1973 Den heliga Birgitta: Ormungens moder som blev Kristi brud. Stockholm: Wahlström \& Widstrand.

1974 Barn och religion (andra utvidgade upplagan). Stockholm: Verbum. 1981a Religionspsykologi. Stockholm: Proprius.

1981b Persona och anima: En tillämpning av C. G. Jungs psykologi på sex författare. Stockholm: Proprius.

1982 Luther's Vorede auf den Psalter von 1545 als Religions-Psychologisches Dokument. - Archiv für Religionspsychologie 15, 36-44.

1983 Konungen och riket: om den gudomliga världsstyrelsen. Stockholm: Proprius.

1987 Saint Augustine and the Psalter in the Light of Role-Psychology. Journal for the Scientific Study of Religion 26, 375-82.

\section{Unger, Johan}

1976 On Religious Experience: A Psychological Study. Stockhom: Almquist \& Wiksell. (Acta Universitatis Upsaliensis Psychologia Religionum 6.)

\section{Wiedel, Björn}

1984 Bön och Tradition: En empirisk religionspsykologisk undersökning av gudsbild och gudsförhållande $i$ samband med bönens form och funktion inom Svenska Alliansmissionen. Lund: Studentlitteratur. (Studia Psychologiae Religionum Lundensia 6.)

\section{Wikström, Owe}

1975 Guds ledning: En explorativ religionspsykologisk studie av fromheten hos ett antal västerbottniska åldringar, med särskild hänsyn tagen till upplevelsen av Guds ledning. Stockholm: Almquist \& Wiksell. (Acta Universitatis Upsaliensis Psychologia Religionum 4.)

1982a De ofrånkomliga orden: religionspsykologiska studier $i$ modern svensk skönlitteratur. Stockholm: Gummesson.

1982b Raskolnikov: Om den kluvnes väg mot helhet i Dostojevskijs Brott och straff. Bodafors: Doxa.

1987 Attribution, Roles and Religion: A Theoretical Analysis of Sundén's Role Theory of Religion and the Attributional Approach to Religious Experience. - Journal for the Scientific Study of Religion 26, 390-400.

\section{Åkerberg, Hans}

1975 Omvändelse och kamp: en empirisk religionspsykologisk undersökning av den unge Nathan Söderbloms religiösa utveckling 1866-1894. Lund: Studentlitteratur. (Studia Psychologia Religionum Lundensia 1.) 
